\title{
On the Affiliation of Phenomenology and Ordoliberalism: Links between Edmund Husserl, Rudolf and Walter Eucken
}

Rainer Klump and Manuel Wörsdörfer*

Forthcoming in: The European Journal of the History of Economic Thought Vol. 18(4) (2011); pp. 551-578.

Abstract: This paper explores the various personal and intellectual links between Edmund Husserl, Rudolf and Walter Eucken. Our interdisciplinary approach gives an insight into Husserl's transcendental phenomenology, Walter Eucken's Ordoliberalism as well as in the interdependency between phenomenology and economics for which Rudolf Eucken's philosophy of intellectual life plays an important role. Particular affiliations between phenomenology and economics can be found in the following topics: epistemology, the idea of man, the comprehension of liberty and the importance of legal or social orders, institutional rules and frameworks of regulations.

Keywords: Husserl; Rudolf and Walter Eucken; phenomenology; Ordoliberalism; social market economy.

JEL Classification: B2, B3, B25, B52, P0 and Z1.

\footnotetext{
* Addresses for Correspondence: Rainer Klump, Chair of Economic Development and Integration and Principal Investigator of the Cluster of Excellence "The Formation of Normative Orders", Goethe-University, Frankfurt/Germany, klump@wiwi.uni-frankfurt.de; Manuel Wörsdörfer, Ph.D-candidate and research assistant of the Cluster of Excellence "The Formation of Normative Orders", Goethe-University, Frankfurt/Germany, woersdoerfer@wiwi.uni-frankfurt.de.
} 


\title{
On the Affiliation of Phenomenology and Ordoliberalism: Links between Edmund Husserl,
}

\section{Rudolf and Walter Eucken}

Rainer Klump and Manuel Wörsdörfer ${ }^{\dagger}$

\begin{abstract}
:
This paper explores the various personal and intellectual links between Edmund Husserl, Rudolf and Walter Eucken. Our interdisciplinary approach gives an insight into Husserl's transcendental phenomenology, Walter Eucken's Ordoliberalism as well as in the interdependency between phenomenology and economics for which Rudolf Eucken's philosophy of intellectual life plays an important role. Particular affiliations between phenomenology and economics can be found in the following topics: epistemology, the idea of man, the comprehension of liberty and the importance of legal or social orders, institutional rules and frameworks of regulations.
\end{abstract}

Keywords: Husserl; Rudolf and Walter Eucken; phenomenology; Ordoliberalism; social market economy

\section{Introduction}

Edmund Husserl (1859-1938) - philosopher and founder of transcendental phenomenology - and Walter Eucken (1891-1950) - main representative of German Ordoliberalism and the Freiburg School of Law and Economics, and thus one of the 'fathers' of social market economy: what do these two illustrious figures of the first half of the $20^{\text {th }}$ century have in common? Did Husserl and his transcendental phenomenology have an impact on Eucken, did he inspire him and if so, in which areas? Was Eucken even an exponent of phenomenology; can he be reconstructed as an economic phenomenologist and his economics as applied phenomenology, as it was claimed by Foucault (2006) and Herrmann-Pillath (1991)? And what role did Eucken's father Rudolf Eucken (18461926), professor of philosophy at the University of Jena and winner of the 1908 Nobel Prize for Literature, play in the transmission of phenomenological thought into economics?

Our paper addresses these questions in four steps. The first part highlights the biographical background and the historical context of the relationship of the Husserl- and Eucken-families. The second part examines the pillars of Walter Eucken's scientific methodology and their

\footnotetext{
$\dagger$ Addresses for Correspondence: Rainer Klump, Chair of Economic Development and Integration and Principal Investigator of the Cluster of Excellence "The Formation of Normative Orders", Goethe-University, Frankfurt/Germany, klump@,wiwi.uni-frankfurt.de; Manuel Wörsdörfer, Ph.D-candidate and research assistant of the Cluster of Excellence "The Formation of Normative Orders", Goethe-University, Frankfurt/Germany, woersdoerfer@wiwi.uni-frankfurt.de. The authors like to thank Walter Oswalt, director of the Walter Eucken-Archive, and Ullrich Melle, director of the Husserl-Archives Leuven, for giving the permission to quote unpublished material.
} 
epistemological analogy with phenomenology. The third section reviews Rudolf Eucken's life world philosophy (Lebenswelt- or Geisteslebensphilosophie) pointing out some of the similarities to Husserl's as well as to Walter Eucken's work. The fourth part looks for affiliations in Husserl's and Walter Eucken's political philosophy. They can be found in the following topics: the idea of man, the comprehension of freedom and humanity, and the importance of legal or social orders, institutional rules and frameworks of regulations. The paper ends with a summary of our main findings.

Contrary to previous works on the affiliation between Edmund Husserl, Rudolf and Walter Eucken this essay differentiates three levels - the biographical, the philosophy of science and the sociopolitical level (incorporating ordoliberal-constitutional, religious and crisis-topic elements alike). All three levels are highly interdependent and interconnected - especially the Gesellschaftskrisistopic functions as an intermediary between the epistemological and the socio-political level. Therefore, it is not sufficient to point just at one level or to separate the levels from each other (as prior research has shown). The first two levels - namely the biographical and the philosophy of science level - are reviewing the results of the German discussion initiated by Goldschmidt, Klump and others. The third level is innovative in terms of pointing at further analogies between phenomenology and Ordoliberalism. This level not only completes our complex and multifaceted interpretation; it also provides the reader with new insights based on the unpublished literary remains of the Eucken-family and especially Husserl (undisclosed material of the Husserl-archive is indicated with Ms.). Furthermore, it is the paper's aim to relativize the influence of Husserl's phenomenology on Walter Eucken: Although Husserl is quite indispensable for Eucken's economic ethics - especially for his epistemological methodology - the role Husserl plays should not be exaggerated in a Foucaultian and Herrmann-Pillathian way: Walter Eucken favours an eclectic approach referring to different philosopher-economists and Rudolf Eucken is at least as much as important as Husserl both(!) on the philosophy of science and the socio-political level. Therefore, the influence of Husserl has to be embedded into the broader context of Eucken's foundation of normative orders. 


\section{Biographical background and historical context}

Husserl and the Euckens knew each other very well. Their first closer contact happened in 1911, when Rudolf Eucken supported the appointment of Husserl to a chair in his department at the University of Jena. ${ }^{1}$ The appointment finally failed due to the resistance of the curator and the provincial government, officially because of Husserl's age, but presumably because of his Jewish ancestry. ${ }^{2}$ But this event did not change Husserl's lifelong appraisal and appreciation of Rudolf Eucken's lifework. ${ }^{3}$ In a letter to his mother (dating from the $7^{\text {th }}$ of March 1936) ${ }^{4}$ Walter Eucken in honoring Husserl's character confirms, that Husserl was all his life very close to Rudolf Eucken's philosophy. In a manuscript (Ms. A IV 17/6b ${ }^{5}$ ) dating from 1910 Husserl himself not only viewed his philosophy of consciousness and Rudolf Eucken's Geisteslebensphilosophie as two complementary sides of the same coin, he moreover confessed himself to Rudolf Eucken's philosophy.

Husserl even condoled with Irene Eucken, Rudolf's wife, on his death (letter from September $17^{\text {th, }}$ 1926), and he wrote a memorial page for Rudolf Eucken's $70^{\text {th }}$ birthday in 1916, which was published in the journal of the Euckenbund, called Die Tatwelt ${ }^{6}$ (1927). The title was Phenomenology and Rudolf Eucken.

It is important to note that the valuation and estimation was not unilateral: Rudolf Eucken approved

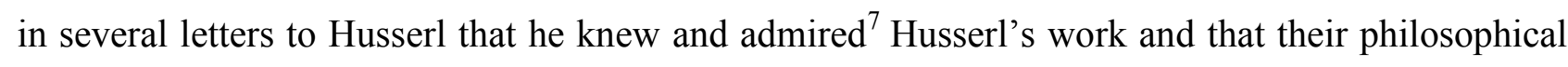
approaches complemented one another: Husserl in his memorial page mentioned above added that Rudolf Eucken's Lebensweltphilosophie ${ }^{8}$ and his phenomenological 'methodology' were supplementary - they were just two different ways of thinking, but they were leading to the same results - and he predicted a unification and a mergence in the near future (Ms. A IV 17/6b).

After Rudolf Eucken's death the contact between Husserl's and Eucken's families not only continued - there was even a remarkable deepening of the relationship and a new, a higher, quality of the correspondence, which from 1927 onwards can be called a true and intimate friendship: 1927 was the year when the first personal meeting ${ }^{9}$ took place: Edmund and Malvine, Husserl's wife, met 
for the first time with Walter and Edith Eucken. Husserl's lifelong appraisal and valuation of Rudolf Eucken's work seems to be the catalysing, the initiating effect of the friendship. It was the common intellectual and ideological fundament. It is reported that Euckens and Husserls got together regularly - almost every fortnight. ${ }^{10}$ They were talking frequently about politics, socio-cultural trends, and of course philosophy. ${ }^{11}$ Husserl even became member of the honouring committee of the Rudolf Eucken house and godfather of Walter Eucken's daughter Irene. ${ }^{12}$ After the National Socialist takeover of power and especially after 1935 Husserl came to be more and more solitary and socially isolated - both professionally and privately. Husserl, who was of Jewish descent, had to suffer a lot of repressions and defamations. Only a few friendships remained: one of them was the loyal comradeship and even devotedness of the national economist Walter Eucken. The relationship to Husserl can be described as supportive, cohesive, intimate and faithful; Husserl himself characterized their companionship as "verstehende und so wertvolle Freunde."13

The friendship lasted until Husserl's death: Euckens were among the few who visited repeatedly his bedside, who attended the funeral, and who joined a commemoration in the context of Diehl's seminar which was quite dangerous in 1938 for all the participants and especially for Walter and Edith because Edith herself was of Jewish origin. After Husserl's death Euckens assisted the widow, Malvine, in practical affairs. They even cared about the literary remains and the philosophical inheritance of Husserl. ${ }^{14}$ However, after Malvine and her husband's remains were brought to Belgium the contact fell almost asleep until Malvine came back to Germany in 1949 - shortly before her death in November 1950. Walter and Edith visited her bedside. In March 1950, eight months before Malvine's death, Walter Eucken died during a lecture tour in London. In a letter of condolence Edith wrote to Elli Husserl, Husserl's daughter, the fact that Walter and Malvine are lying near to each other further symbolizes the closeness of the Husserl- and Eucken-families.

Worth mentioning is the piece of information that among other friends in Husserl's late Freiburgyears were $\mathrm{Karl} \mathrm{Diehl}^{15}$, professor of economics, and Gerhard Ritter, professor of history - at the same time friends and colleagues of Eucken, and core members of the so called Freiburg circles. The Freiburg circles were resistance circles against National Socialism gathering around the 
Bekennende Kirche, an oppositional movement of the Protestant Church. The fact that Husserl was a friend of Ritter and Diehl, and the fact that he was himself(!) a member of the Bekennende Kirche ${ }^{16}$ further indicates, that there existed a personal bond between Eucken and Husserl besides the methodological or analytical one. ${ }^{17}$

\section{An Epistemological Comparison between Edmund Husserl and Walter Eucken ${ }^{18}$}

It is common sense that Husserl shaped or formed Walter Eucken's analytical methodology however, the degree of influence is somewhat controversial, and it is at least debatable whether phenomenology is a kind of meta-theory (Herrmann-Pillath 1991; Weisz 2001) or the quasifoundation of Ordoliberalism (Foucault 2006). In this paper we argue that Husserl's phenomenology was quite essential for Eucken's own way of theoretical thinking; nonetheless the epistemological influence of Husserl on Eucken does not have to be overestimated in a way that Eucken's style is hard to imagine without Husserl, because Eucken uses a somewhat eclectic and syncretistic approach combining and rearranging different elements from different thinkers.

There are at least six ${ }^{19}$ explicit quotes of Husserl in Walter Eucken's work. The first two explicit references to Husserl and phenomenology are contained in Eucken's essay Was leistet die nationalökonomische Theorie? (1934) ${ }^{20}$ This work in addition to Staatliche Strukturwandlungen und die Krisis des Kapitalismus and Nationalökonomie wozu? is often referred to as the nucleus of Ordoliberalism. In two footnotes on pages 29 and 31 Eucken refers to Husserl's Logical Investigations (LI). Especially the first one is in this context relevant. Eucken distinguishes two scientific approaches of economic reasoning - the rationalistic-theoretical and the empiricalhistorical one. He aims at bridging the gap and reconciling both seemingly dichotomous methodologies - the first one mainly used by the Austrian School, the latter one attributed to the Historical School. He aspires to overcome the Great Antinomy in economic methodology, the Methodenstreit, as well as the (scientific) crisis of humanity by laying a revolutionary new methodological fundament of science in general and economics in particular: he intends to establish economics as a rigorous and crisis-proof ${ }^{21}$ science - to use the Husserlian expression - and 
searches for a solid and absolute epistemological basis of economics: a search seeking evidence, objectivity, apodictic truth and ultimate justification based on an eidetic cognition, as Husserl puts it. In order to succeed he favours a four-stage procedure: the first step contains the raising of a general theoretical problem by observing and inspecting unprejudicedly and dispassionately ${ }^{22}$ the historicempirical reality, the multiplicity of accidentally coexisting individual economic phenomena and their apparently disjointedness or incoherence - it is their interconnectedness and interdependency which has to be unveiled by economic scientists ${ }^{23}$ : daily economic experiences and everyday economic life $^{24}$ at all times and places encloses, according to Eucken, phenomena with a high degree of uniformity and generality; today we would speak of stylised facts abstracting from contingency, randomness and singularity. Eucken's prime example is economic exchange; other examples are the phenomena of goods scarcity, planning, the coordination of individual plans via the price mechanism, and the eidetic entity (artificially constructed) competition. ${ }^{25}$ The task of the scientist is on the one hand to disclose the common bond, the coherence of such phenomena (invariant general form ${ }^{26}$ ) and on the other hand to discover the essential elements, the essence ${ }^{27}$ of such phenomena, capture them and infringe on or enter into the character, the nature of these phenomena. In Husserl's terms: it is significant to radically steer towards and penetrate (in-)To things themselves (Hua XIX/1, 10). ${ }^{28}$ Husserl as well as Eucken are concerned with phenomenology respectively economics as an a priori eidetic science or science of essence. In order to succeed Husserl, Eucken and Weber claim that it is extraordinarily important to refrain from value judgements of any kind and to preserve the pureness of looking. ${ }^{29}$

The way to things themselves is the path of abstraction and eidetic reduction ${ }^{30}$ with the aim of deducing pure economic forms and extracting purely ideal types as a heuristic device (step two): a complexity reducing tool, by theoretically enhancing certain aspects of real phenomena while neglecting others. Everyday economic reality can be reduced - via the ideal type method of abstraction - to pure economic forms. Here Eucken combines Husserl's method of abstraction and reduction with Weber's ideal type approach, and thus goes beyond phenomenology. One request of these ideal types is their closeness to reality although they are quite abstract, theoretically 
constructed and won by the method of reduction. Eucken gains via this (Thünen-like) technique, which he calls pointedly distinguishing or isolating abstraction (Eucken 1952/2004: 378) ${ }^{31}$ ), two purely ideal types or forms of economic order: centrally directed economy and exchange economy. Step three implicates the development of an adequate morphological economic model and the extraction of an economic theory. The core criteria here are twofold: economic theories or models should on the one hand fulfil the criteria of accuracy, exactitude, and closeness to reality; they should especially reveal economic interconnections. But on the other hand they should also meet the criteria of evident and rationalistic-objective truthfulness: Eucken speaks of a Wesenswahrheit ${ }^{32}$, an evident truth of reason (Eucken 1934: 29), as the final goal of theoretical knowledge which is almost identical to Husserl's theory of evidence. ${ }^{33}$

The fourth step is just the implementation of the derived model by using the method of generalising instead of isolating abstraction (cp. Eucken 1950/1965: 168): By applying the theory to economic reality it should be possible to understand and explain everyday $\operatorname{life}^{34}$, and therefore, eventually modify and frame it via economic policy.

Eucken's early masterpiece, the Foundations of Economics (Eucken 1950/1992), picks up, condenses, and elaborates essential features and implications of his earlier epistemological and methodological writings; the careful reader of the book will find - mostly in the appendix - four explicit references to Husserl: the first one is an explicit statement drawn from Husserl's LI, and by quoting Husserl Eucken applies directly early phenomenology to economics. Husserl (as cited in Eucken 1950/1992: 304):

"The systematic character of a science, if genuine, is not something invented, but lies in the facts, and its existence therein has to be discovered. A science must be the means by which the realm of truth is extended, and this realm is no disordered chaos but governed by uniformity and regularity."

Husserl's as well as Eucken's epistemological aim is to establish a true, i.e. ultimately justified and crisis-proof science and via this so called Philosophy as a Rigorous Science - to use a title of one of Husserl's essays and lectures - to arrive at (Rudolf Eucken's) realm of truth ${ }^{35}$ Husserl (as cited in Eucken 1950/1992: 321): 
"On the methodological task here the question how confused naïve experience can become scientific experience and how objectively valid empirical conclusions can be arrived at is the principle methodological problem of every empirical science."36

By referring again to the LI Eucken (1950/1965: 253) shares Husserl's criticism of the so called Begriffsnationalökonomie incorporating a renunciation of mere terminological questions, and the turning towards things themselves, the fathoming into the essence of (economic) phenomena. On the following page Eucken cites Husserl's LI in order to support his view of distinguishing two types of abstraction or a two-stage abstraction method (Eucken 1950/1965: pp. 70/123124/168/226/249 and 254): the pointedly distinguishing abstraction focusing on the enhancement of particular aspects ${ }^{37}$ of individual phenomena, and the generalising abstraction overviewing several phenomena and generic terms. ${ }^{38}$ The first one is mainly related to ideal types while the latter is closely related to the application of Eucken's morphology and to real types used by the Historical School, and so linking the approaches of the Historical and the Austrian School, and solving the Great Antinomy. Eucken (1950/1992: 299) marks the difference as follows:

\footnotetext{
"It is of decisive importance [...] that the right method of abstraction is adopted and rightly applied. [Pointedly distinguishing] Abstraction must be primarily by distinguishing the significant characteristics, as in studies of single economic units, thus enabling the real economic world to be grasped and understood. [...] “Generalising" abstraction involving withdrawal from actual economic phenomena must take second place. It has a certain part to play in the scientific definition of economic systems and in discovering the dominant and supplementary elements in their structure." 39
}

Except the passage where Eucken is quoting Husserl literally, these passages have two things in common: Eucken does not base his argument solely on Husserl; he also refers to other philosophers and scientists. Furthermore Eucken is mostly concerned with or using evidence from Husserl's LI, and these are the two crucial points for our theses, namely that Eucken's argumentation and methodology is not only relying on Husserl, and that he - in the case of borrowing from Husserl neglects or misses some of the central aspects of Husserl's philosophy (e.g. intersubjectivity- and life-world-theory).

The two volumes of the German edition of the LI were published at the turn of the century - to be precise in 1900/1901. Although this work is quite essential for the philosophy of transcendental 
phenomenology it nevertheless belongs to Husserl's earlier works ${ }^{40}$ - the so called Halle-Period (1886-1900) mainly influenced by Brentano's criticism of psychologism and accentuation of intentionality ${ }^{41}$ - while his late work, that of the Göttingen (1901-1916) and Freiburg Period (19161938), contains some more elaborated aspects - even with regard to epistemology and methodology (Hua VI and XXIX), not to mention Husserl's Ideas Pertaining to a Pure Phenomenology and to a Phenomenological Philosophy, Formal and Transcendental Logic, the concept of space and time consciousness, and the theory of intersubjectivity (Hua XIII-XV). It is noteworthy that until 19051910 Husserl's vocabulary did not contain expressions like reduction, epoché, and noema. Even Husserl (1956: 298) himself expressed his dissatisfaction with the LI: he regarded his early masterpiece as not sufficient, not satisfactory and not systematically enough - compared with his late work. In short: The LI are just the beginning of phenomenology. According to Brecht (1957) the Halle-Period - of which the LI are a part of - can be described as a pre-phenomenological phase, and Mohanty (1995) adds that it is possible to separate the development of Husserl's thought into the following categories: (anti-)psychologism, essentialism, transcendental idealism, and philosophy of the life world ${ }^{42}$ : Husserl's LI belong to the first two categories.

Beside the literal references to Husserl which can be found in the oeuvre of Eucken, there are also implicit epistemological references e.g. in Eucken's newspaper-article on the occasion of a Mackeexhibition. Eucken (1935: 10) claims that a pursuit of realness and objectivity is crucial as well as the interpenetration and interfusion of essential contents.

Furthermore Edmund Husserl, (Rudolf and) Walter Eucken criticize historism, positivism, and relativism. In an essay published in 1938 Eucken pleads for the Overcoming of Historism - and indirectly for the founding of science on ultimate grounds -; in this context he considers his father and Husserl as being an exception by non-supporting historism. Eucken uses evidence in this case not from the LI - which is quite remarkable because it is extraordinary - instead he refers to Husserl's late work The Crisis of European Sciences.

\section{The influence of Rudolf Eucken's philosophy of intellectual life}


It is noteworthy that the central topics of Husserl's Kaizo-essays and his Crisis-work - namely the stating of a present-day cultural failure, a crisis of values including a crisis of the European humanity, and therefore, the necessity for an ethical and political reformation of culture ${ }^{43}$ aiming at the implementation of the ideal of a humanity of reason ${ }^{44}-$ are anticipated by Rudolf Eucken's socio-critical philosophy ${ }^{45}$ : the Nobel Prize laureate of 1908 condemns the dominance of the onesided and shallow technical-mechanical, instrumental and materialistic-utilitarian ${ }^{46}$ working-culture (Arbeitskultur), its disorientation and alienation of the people, and at the same time the neglect of the intellectual and cognitive sphere (Geisteskultur) ${ }^{47}$ in mass societies; in other words: he (and later on his son using a similar terminology (Heinrich/Eucken 1926, 1927, 1930 and 1932a)) denounces the soullessness and worthlessness of modern culture. The reciprocal fertilization of Arbeits- and Geisteskultur, Intellektual- and Realkultur is missing - a reason for the calamity of present-day European culture. Rudolf Eucken in line with Husserl is appealing to individual intellectual freedom, independence, and autonomy - however, he is quite critical of radical individualism; social cohesion has to be preserved. He reckons upon the individual human being enlarging his or her own mental capabilities (Bildung der Seele), and to participate in the divine Geistesleben based on Christian values and within a society relying on tradition and Geisteskultur. What is necessary according to Rudolf Eucken is the overcoming respectively the solving of the dichotomy or the field of tension between individualism and socialism, idealism and realism; a synthesis is needed between empiricism and rationalism, and between Innen- and Außenkultur in connection with a radical renewal and reformation of the selfs (a so called Selbst- or Wesenserneuerung) seeking freedom and truth.

The resemblances to Husserl's Kaizo-articles are astonishing: they were written a year before its publication in 1923/4 in the Japanese magazine with the same wording. Kaizo simply means reform or renovation. Husserl wrote in total five essays on the subject of ethical as well as socio-political reformation of mankind, culture, and science, a topic with which Husserl was busy and preoccupied especially in the post-war-years; at the end only three of them were published. The essays are a careful analysis of (European) civilization and the socio-political situation of Germany in the early 
years after World War I. Husserl pleads for a European Vernunft- and Kulturmenschheit, a society marked by reason and objectivity (i.e. realm of truth), freedom and autonomy, and last not least humanity. A pre-requisite for continuously individual as well as social renewal is phenomenology or generally speaking philosophy as rigorous science incorporating all the epistemological items mentioned above: science as a pure and a priori science of essence, the eidetic method etc. In total there exists a close link, a quasi Eucken-like interdependency between Husserl's epistemological analysis and his socio-political and ethical writings (the Kaizo-essays fit perfectly into, they are part of Husserl's political philosophy which will be discussed in the subsequent paragraph). Furthermore these essays are intermediating and connecting Husserl's Philosophy as Rigorous Science and the Crisis-book.

Moreover Rudolf Eucken's epistemology and methodology is preceding that of Husserl: he uses a method of abstraction and reduction, and a Weberian method of isolating ideal types as well. He calls this technique noological method ${ }^{48}$ which is close by the phenomenological approach. He aims at the substance or the being of facts, he highlights the entirety, totality, the intuitive, direct and straight look, and the advance towards the essence, and he pursues - in complete concurrence with Husserl - the realm of truth. ${ }^{49}$

This affiliation between phenomenology and Rudolf Eucken's philosophy of intellectual life which is confirmed by Husserl and Walter Eucken ${ }^{50}$ as well as the fact that Walter admired his father and looked upon him all his lifetime as a role model ${ }^{51}$, all these facts make it even more complicated stating the thesis that Walter Eucken is solely relying on Husserl. It is most likely that Eucken came first into contact with the method of reduction and with the cultural crisis topic (i.e. nihilism, loss of ethical values and the necessity of an intellectual renewal ${ }^{52}$ (cp. Heinrich 1926; Eucken 1927, 1930 and 1932a)) via his father's philosophy, and not via Husserl's phenomenological approach. Rudolf Eucken seems to be the missing link between Walter Eucken's normative economics and Husserl's phenomenological philosophy of consciousness and intuitionism. ${ }^{53}$ Nevertheless it is essential to state that Husserl, Rudolf and Walter Eucken are at least familiar with similar subjects - on the philosophy of science level as well as on the upcoming cultural and political level. 


\section{Husserl's and Walter Eucken's Political Philosophy}

Husserl did not write a systematic political treatise ${ }^{54}$; he even characterized his transcendental phenomenology in a letter to his son, who was himself a lawyer, legal scholar and applied phenomenologist ${ }^{55}$ (dating from the $5^{\text {th }}$ of July 1935) as completely un-political; however, we have to take into account the historical context of the political circumstances of the Nazi regime, and Husserl's own biographical background: the exclusion of state, law, and politics in his publications can be seen in some ways, and among other things, as a reaction to the political conditions of his time. Instead of emigrating Husserl chose the way of the inner exile and escapism, and sought shelter in the world of philosophical ideas; he turned towards introspection, and religious and existentialist spirituality. ${ }^{56}$

Nevertheless it is possible to develop carefully on the basis of intersubjectivity theory a rough sketch of his philosophical ideal of state and nation ${ }^{57}$ - especially his ideal of a state as a guarantor (together with phenomenology) of individual as well as socio-ethical teleological development via the constitutional prevention and mediation of conflicts -, and then in a next step to compare this ideal with that of (Rudolf and) Walter Eucken, and to point out some of the limits of such a resemblance: Husserl - alike Marx but in stark contrast to Walter Eucken - was convinced that in case of the realisation of the ideal of a phenomenological based culture the state apparatus itself would become superfluous and unnecessary. The state is in Husserl's conception no end in itself, no final objective, it is only an instrument, a mean to reach the phenomenological ideal of humanity; after completing its mission (i.e. enabling teleology) the government, and all the other formal institutions abolish and disintegrate. Walter Eucken on the other hand was quite critical of teleology in general - especially teleology in context of the Historical School. However, it cannot be said whether he was also critical of (Husserl's) rationalistic teleology (i.e. the continuous and teleological pursuit of reason respectively the ideal of a humanity of reason as the overall telos).

Husserl's political philosophy is embedded and bound up with his other writings, especially with the theory of intersubjectivity, the already mentioned Crisis work and the Kaizo-articles, and its call 
for a reformation of mankind as a reaction to the disorder of those days and the breakdown of the order of civilization. The overriding principle of Husserl's political philosophy is the idea of a purely reasonable and rationalistic social community, a higher ethical order of absolute or transcendental beings. However, it is important to note that Husserl links this ethical rationalism and the concept of renewal with an ethical theory of love; the two basic motives of Husserl's ethics are reason as the highest value of European enlightenment and love respectively humanity. Starting at the individual-ethical level each individual is able and required to completely, i.e. steadily, activate and unfold her or his innate rationalistic abilities, and to overcome fatalism, inertia and mental immaturity. Husserl's idea of man (Ms. B I 21 I) is marked by the emphasis on selflegislating and self-regulating autonomy, freedom ${ }^{58}$ through rationality (Hua VIII 230), selfconfidence, and self-knowledge (as means to obtain happiness), and finally individual as well as social responsibility. Husserl's Categorical Imperatives ${ }^{59}$ are: "Live a life in accordance with reason and prudence!", "Be a true human, lead a life that you can justify thoroughly in an insightful way, a life lived from out of practical reason" (Hua XXVII 36), "Be eager and act rationally", and "I can act”! Every human being should pursue a (completely) reasonable lifestyle; each person is required to steadily reflect one's life, and if necessary to revive it.

The image of humanity in combination with the ethics of renewal presented by Husserl thus goes together with the ideas of man of Kant, Rudolf and Walter Eucken. ${ }^{60}$ Compare the following quotes: Walter Eucken (1952/2004: 176): "Without freedom, without autonomy, a human being would not be a "human being"” (translated). Husserl states:

"Reason is the specific characteristic of man [...]. Human personal life proceeds in stages of self-reflection and self-response from isolated occasional acts of this form to the stage of universal self-reflection and selfresponsibility, up to the point of seizing in consciousness the idea of autonomy, the idea of a revolve of the will to shape one's whole personal life into the synthetic unity of a life of universal self-responsibility and, correlatively, to shape oneself into the true "I", the free autonomous "I" which seeks to realize his innate reason $[\ldots][\mathrm{W}]$ hat follows from this is the ultimate self-understanding of man as being responsible for his own human being: his self-understanding as being in being called to a life of apodicity, not only in abstractly practising apodictic sciences in the usual sense but (as being mankind) which realizes its whole concrete being in apodictic freedom by becoming apodictic mankind in the whole active life of its reason [...] [U]ltimate self- 
understanding has no other form than self-understanding according to a priori principles as self-understanding in the form of philosophy." ${ }^{61}$

Accountability and liability - together with a common spirit of supra-individual humanity - are the terms linking the individual-ethical and the socio-ethical or communal level because of their twofold character: responsibility is first of all concerned with each individual (to be responsible for one's actions and to be responsible for the degree of reasonableness); furthermore there exists also a capability of transcendental empathy (Ms. B I 21 III/IV) combined with a sense of solidarity and responsibility for the communion as an intellectual (i.e. rational) community of ethical love (Hua XIII 107). Husserl bases his argument on the assumption that there exists an underlying, an original tendency towards the formation of associations and communities: Leibniz' monads are striving to community. The main task of the state apparatus is to guarantee and foster this teleological development towards the realisation of omnipresent ratio by not intervening massively and by providing the necessary institutional framework; it is the necessary condition for the realization of teleology: it sets limits to dysteleological forces - tasks quite similar to that of Ordoliberalism and social market economy. Husserl is primarily interested in those institutions that can prevent disharmony, mediate, and resolve conflicts among the inhabitants of the state. Especially the legal system and the rule of law ${ }^{62}$ (Hua XIII 107 and XV 48) are responsible for a peaceful, harmonious, and humane ordering ${ }^{63}$ respectively development (Hua XV pp. $407^{64}$ ). In combination with the enlightening role of transcendental phenomenology as a scientific philosophy ${ }^{65}$ the state is the external frame for the realisation of the intersubjective telos: the institutional framework should leave enough space for personal freedom, cultivation to rationality, and individual self-realization. Together they are in a sense 'tools' for reaching the status of an autonomous rational and ethicalhumane mankind, a universal culture. The form of government that fits best into this context is a democracy-based rule of law. ${ }^{66}$ In manuscript A II 1 Husserl not only favours the constitutional state, he even plays with the idea of a constitutional state in the hand of a phenomenological elite as the ideal state. According to Husserl the highest possible form of positive law requires a philosophical - i.e. a phenomenological - founding. 
A key demand in order to carry out the state's assignments is the independency and neutrality of the government agencies. The state must be self-determining and free from special interest groups. The state is a 'personality' of a higher, superior order, and the private and public-political spheres must be separated. The state is ethically indifferent in the sense that it treats all people equally (Hua XIV 90/182/405 and XV 413). This sounds quite familiar from an ordoliberal perspective. Husserl even touches Eucken's topics of state-guaranteed private property (Ms. B I 15 III), and the limits of state affairs: according to Husserl the boundaries of politics are reached at that point when all the legal laws are obeyed.

Husserl's supreme state of community is an open, Polis-like community (Hua XIII 109 and XIV 182) with a communitarian concord of will, a public spirit, a bonding group identity, and equal civil rights and obligations. Everyone can join (and leave) freely the truly 'love community' - referring to the universal character of this community. ${ }^{67}$

On a preliminary stage, and contrasted with the higher order community, the society equals an artificial club-like association with shared pragmatic and functional interests, and based on a reciprocal contract. This club-model is due to its utilitarian focus of minor (ethical) quality; however, it is an essential interim solution on the (teleological) path towards the rational and reasonable love community.

The highest form of the life of monads is intellectual love respectively the intellectual love community with its unity of self-love, self-interest, benevolence, charity, and public welfare. ${ }^{68}$ Humanity and reasonableness are the final goals, the telos of the monad-evolution. Such a society, so to speak, combines the ideals of Vernunftmenschentum and the ideal of echte Humanität (i.e. Eucken's humane order). It transcends egoism, materialism, instrumental reason, and it embodies the true and real age of enlightenment (Hua XXVII 117).

However, it is essential to note that when the final stage, the stage of rational und humane mankind, and the kingdom of pure and rigorous science and logical reason (Hua XXVIII 57/59), is reached the state machinery is once and for all going to be abolished and disintegrated (Hua XXVII 58): everyday life is then 'ruled' by phenomenology; in a sense life in the phenomenological community 
is somewhat anarchical. The state is no longer necessary, simply because there are no constraints, hierarchies or positions of power (Ms. F II 7/55b). The state's, and all the other external powers and authorities, have vanished; they have been transformed via phenomenology leading to an rational insight into absolute ethical values (Ms. A II 1/6b), and an internalization and incorporation of phenomenology. Transcendental philosophy is the state's legitimate successor, it pervades all parts of society, and the individuals are now completely self-responsible and autonomous. This aspect of Husserl's ethical philosophy goes far beyond Eucken's outlook. Due to Walter Eucken a strong, yet not totalitarian state as a guardian of the competitive order respectively as a guarantor for order and competition (Eucken 1952/2004: pp. 325) is indispensable - in order to ward off interest groups, and to avoid being a play thing in the hands of rent-seeking groups.

Coming back to two of the key terms of the former paragraphs: Freedom and humanity are the expressions which link Husserl's conception of ethics to that of Walter Eucken: since the Tatweltarticle Die geistige Krise und der Kapitalismus Eucken's aim was the realisation of an ordering which fulfils the criteria of economic efficiency and functionality on the one hand as well as the criteria of individual freedom (i.e. autonomy and self-reliance) and humanity (i.e. human dignity and human rights) on the other hand (Eucken 1952/2004: 14). According to Eucken freedom is threatened in three ways (Eucken 1952/2004: 177): first of all it is threatened by private power of the producers, secondly it is threatened by the collective or the society (i.e. danger of group anarchy), and thirdly by the power of the state. ${ }^{69}$ The best way to encounter such menaces is to establish an economic Ordnungspolitik ${ }^{70}$ (incorporating Eucken's two principles of economic policy as well as his constituting and regulating principles) which while focusing solely on the rules of the game (order of rules) can handle or balance the dilemma of freedom and order. Economic policies that institutionally frame - in the sense of defining the general terms under which market transactions are carried out - instead of influencing or intervening into market processes and the play itself (order of actions) as the Prozesspolitik would do, are requisite in order to establish Leistungswettbewerb and consumer sovereignty (competition in terms of better service to 
consumers). But at the end the constitutional order is a mean to an end - freedom and humanity (Eucken 1952/2004: 199/324).

In Husserlian and (Neo-)Kantian ${ }^{71}$ terms we can interpret Eucken's conception as follows: the aim of the constitutional order and the formal legal-institutional framework, especially the state under the rule of law and its checks and balances is to hold in equilibrium individual and social ethics, personal interests and public welfare, and to enable (economic as well as intellectual) independency and autonomy. Leistungswettbewerb and Ordnungspolitik together allow for a raised standard of living, and hence a higher level of external happiness. Furthermore they also set up the basic conditions for internal (i.e. intellectual) happiness incorporating mental liberty and maturity.

It is this metaphysically and ethically embedded defense of freedom and Christian based humanity (within his concept of Ordnungstheorie) which is at the heart of Eucken's life work - and to a lesser degree the methodological issues discussed above; they are important, no doubt, however, they are not as much essential as Eucken's passionate and fervent fight against National socialist, Communist as well as libertarian or laissez-faire ideologies. ${ }^{72}$ Therefore, an (reductionist) absolutization of Husserl's phenomenology seems to be inappropriate in two ways: first, regarding the fact that Eucken's epistemology is based on multiple sources; secondly, regarding the fact that his methodology is just an instrument or a tool in order to overcome the Gesellschaftskrisis (by reaching the realm of truth via a crisis-proof science) and in order to explore economic systems capable of meeting the twofold condition of a functioning and humane socio-economic order based on religious values.

Before coming to a conclusion it is noteworthy touching upon some further similarities in the thinking of Husserl and Walter Eucken: first of all it is obvious as already mentioned that their understanding of freedom and humanity is quite equal. This can also be illustrated in a more theological or religious way: both Eucken and Husserl were devout and pious Christians, they are both making clear reference to Christian faith, and they were both members of the Bekennende Kirche. In the end their philosophical systems rest upon God. 
In a letter dating from 1942 Eucken's philosophy of religion becomes clear. He admits: „I could not exist, nor work, if I did not have a clue of God's existence“ (translated). ${ }^{73}$ In an essay called Religion - Wirtschaft - Staat (1932a) Eucken detects an absent meaning of life in the presence and a crisis of values resulting from the steering towards materialism, and an alienation from religion and the hereafter. ${ }^{74}$ Christian faith is the only way to fill the ethical vacuum and to restore the endowment of life with meaning and an encompassing unity of life. On a conference of the Euckenbund Eucken claimed that the religious renewal of mankind was the fundament of any other kind of reformation including an economic and political one ${ }^{75}$, and in his Grundsätze-book Eucken claims that religion could be a potential ordering power, together with science and the state.

Husserl by his own account had to fulfil a religious mission. One of his life mottos was: Only those grounding their lives on God will receive new energies. ${ }^{76}$ Adapted from Cairns (1976: 47) Husserl stated that ethical and religious questions are the fundamental, the last questions of phenomenology (Ms. A V 21/22). Especially in the 1930ies Husserl was well acquainted with borderline situations, and he mainly dealt with basic existential problems like religious spirituality, fears, illness, and death.

Both Husserl and Eucken are propagating a non-dogmatic and non-superstitious religion, and they are pleading for tolerance - not only in religious terms. Husserl saw himself as a free Christian and an un-dogmatic Protestant: "The world is conceived as the work of a good God ... Tolerance then for religion, but intolerance for theologians". ${ }^{77}$

Furthermore Husserl, Walter (and Rudolf) Eucken are warning against the dangers of nihilism, stereotyping, and the decay of reasoning (e.g. Eucken 1933) potentially leading to a Crisis of European Sciences (Husserl); they are fighting - albeit with deviating means and on differing scopes - historism, naturalism, positivism, irrationalism, relativism, and (modern) scepticism (e.g. Eucken 1933, 1938b ${ }^{78}$, and Böhm, Eucken \& Großmann-Doerth 1936) by demonstrating that objectively valid, true and eternal in contrast to arbitrary, context based, temporary and random (scientific) knowledge is possible, and by combining analytical validity and empirical application. 
This leads us back to the epistemological level showing again the strong interdependencies between the methodological and the cultural and socio-political level.

They also advise against the overassessment of specialists with their limited and biased perspectives and their one-sidedness; so they are fighting Punktualismus and Spezialistentum, to use the German expressions (Hua V 13/22/95-96, XXVII 115). According to Walter Eucken (1952/2004: pp. 338) science can become an ordering power, provided that it is successful in overcoming the three mentioned prejudices: positivism, historism, and Punktualismus. ${ }^{79}$

Husserl as well as Walter Eucken are pleading for a critical and independent assessment and scrutinizing respectively challenging of various authorities in line with Kant's sapere aude. In this context Husserl is highlighting the enlightening function of philosophy in general and of phenomenology in particular (by its endowment of life with meaning and by leading mankind to self-confidence, rationality, and free will (Hua VII 205 and VIII pp. 193)); Eucken on the other side accentuates the similar task - the enlightening effect - of science in general.

\section{Conclusion}

Everyday economic life and facts derived from everyday life are Walter Eucken's epistemological starting point. Via applying an analytical raster which interlinks (Weberian) ideal-type- as well as (Rudolf Euckenian, Husserlian, and Thünenian) isolating-abstraction-elements it is possible to deduce theoretical knowledge arriving at (Husserl's and Rudolf Eucken's) realm of truth. Pointedly distinguishing abstraction simply means interpenetration of economic reality, radical turn towards reality, steering towards eidetic essences and the founding of an atemporal valid morphology. Eucken's slogans are: "Durchstoß zur wirtschaftlichen Wirklichkeit", "wissenschaftliche Durchdringung der konkreten Wirtschaft" and "die Beobachtung der wirtschaftlichen Wirklichkeit auf die Spitze treiben" (Eucken 1950/1965: pp. 21/226). The feedback of the evident truth of reasons enables the overcoming of the scientific dualism of theoretical and historical economics (i.e. Great Antinomy and Methodenstreit); moreover it allows the founding of a crisis-proof science and in this respect associates the philosophy of science level with the ethical and the political level. 
To sum up the theses presented in this paper: first of all Husserl's phenomenology rests on many pillars, and Eucken absorbs just a few (especially early phenomenological elements): central aspects of the philosophy of consciousness are not at all taken into account, others are chosen quite selectively and out of context. But this is nothing to get upset about it, because Eucken represents a syncretistic and eclectic approach (second thesis), and he seems to be more concerned with the fight against totalitarian ideologies of any kind and his standing up for ordoliberal freedom and human dignity (compared with his epistemological efforts), which is our third thesis. All this goes along with the underlying thesis of our paper that an absolutization of Husserl's philosophy is inappropriate - especially when taking Walter Eucken's eclecticism into account (i.e. explicit references to Rudolf Eucken, Husserl, Weber, Thünen, Kant et al.). ${ }^{80}$ Moreover, Walter Eucken regarded himself as a disciple of his father and in fact Rudolf Eucken's noological method (aiming at the realm of truth) as well as his analysis of the crisis-topic shaped Walter Eucken's economic ethics both on the methodological as well as on the cultural and socio-political level. Last not least Husserl's admiration of Rudolf Eucken's Lebensweltphilosophie and the far reaching analogies between Rudolf Eucken and Edmund Husserl relativize the effect of Husserl while raising the influence of Rudolf Eucken: Eucken senior seems to be at least as important as Husserl - refusing the thesis that Eucken's Wirtschaftsordnungspolitik has a (solely) phenomenological basis and that phenomenology were a meta-theory of Ordoliberalism. ${ }^{81}$ Although we are denying the absolutization of Husserl's phenomenology and refuting the Foucaultian and Herrmann-Pillathian reductionism from an Eucken-perspective we are not (totally) neglecting the eminent role phenomenology plays regarding the foundation of Eucken's normative (socio-economic) order. Contrary, we are well aware of this line of reception; that is the reason for differentiating between a biographical level of personal friendship and an epistemological level. In addition we are including a third level of analogies - namely the cultural or socio-political level - which is highly interconnected with the other two levels - rounding the complex economic-ethical system of Walter Eucken.

\footnotetext{
${ }^{1}$ See the correspondence between Rudolf Eucken and Husserl in: Husserl 1994b
} 
${ }^{2}$ Cp. Dathe 1993 and Graf 1996

${ }^{3}$ Husserl studied and absorbed Rudolf Eucken's writings since the 1880/1890ies (cp. Dathe 2009: pp. 20).

${ }^{4}$ All quoted letters are contained in the Nachlass-files of the Eucken-family (cp. Eucken,W. (1908-1926/1935-1937):

Briefe von Walter Eucken; Jena, Thüringer Universitäts- und Landesbibliothek: Nachlass Irene und Rudolf Eucken).

${ }^{5}$ Manuscripts indicated with Ms. are unpublished materials of the Husserl-Archives Leuven.

${ }^{6}$ The Euckenbund was an ideological movement agitating and fighting against the cultural and intellectual deprivation of Germany while at the same time promoting the ideal of an intellectual life in accordance with Rudolf Eucken's Lebensweltphilosophie. Die Tatwelt was the journal of the Euckenbund, mainly published and organized by members of the Eucken-family.

${ }^{7}$ He even called Husserl one of the leading philosophers of contemporary Germany (Rudolf Eucken 1924: 7); see also the correspondence between Husserl and Rudolf Eucken in: Husserl 1994b.

${ }^{8}$ Fellmann (1983) even speaks of "Lebensweltphänomenologie".

${ }^{9}$ The first philosophical contact between Husserl and Walter Eucken was probably initiated by Rudolf Eucken: Rudolf and Walter had a lot of philosophical discourses and exchanges. Especially in the years when Rudolf Eucken studied Husserl intensively (1911/1924) he had a close (philosophical) relationship with his son as well (cp. Dathe 2009). These periods were from Walter Eucken's point of view shaped by his engagement for the Euckenbund. After Rudolf Eucken's death, while preparing the memorial edition of Die Tatwelt, Walter together with his wife Edith analyzed Husserl's philosophy.

${ }^{10}$ Cp. Eucken-Erdsiek 1981: 62.

${ }^{11}$ Edith as well as Walter Eucken were both well skilled philosophers. Edith was studying philosophy, literature and economics, and attending Husserl's seminars (as a guest auditor), while Walter was educated in philosophy by his father (cp. Klinckowstroem 2000 and 2005). He was also lecturing about Socrates, Spinoza, and Galileo (cp. his lecture Der Kampf der Wissenschaft).

${ }^{12}$ Cp. Husserl 1994c: 99: In this letter Husserl expresses his gratitude for having Euckens as close friends in such a severe and harsh political period. The chance to become the godfather of Irene was a symbol of Euckens' bona fides.

${ }^{13}$ Letter from Husserl to E. Rosenberg from the 9th of October 1935 in: Husserl 1994c: 462 (cp. pp. 460; Ms. A V 8/4b (here Husserl gave authority/full powers to Walter Eucken) and the chapter Eucken-Erdsiek (1981: pp. 57) devoted to the personality of Husserl and their relationship).

${ }^{14}$ Cp. Vongehr 2009: pp. 10

${ }^{15}$ Cp. Husserl 1994b: 181

${ }^{16} \mathrm{Cp}$. letter from Malvine to J. and E. Rosenberg (from the $10^{\text {th }}$ of November 1934; Husserl-Archives Leuven); see Vongehr 2009: 8 


\footnotetext{
${ }^{17}$ Cp. Vongehr 2009: pp. 5

${ }^{18}$ Cp. for foundation: Klump 2003, Goldschmidt 2002, 2003, 2009, Goldschmidt \& Rauchenschwandtner 2007 and
} Meijer 2007.

${ }^{19}$ Here, we are referring only to the explicit or literal quotes; the implicit quotes are mentioned later on in this chapter. Goldschmidt 2002 and Goldschmidt \& Rauchenschwandtner 2007 mention seven citations in total, without differentiating between implicit and explicit quotations.

${ }^{20}$ According to the files of the Husserl-Archives Leuven, this essay was the only Walter Eucken-paper that was located in Husserl's library (the book contains a hand-written tribute to Husserl by Eucken, but no comments by Husserl).

${ }^{21}$ Eucken literally borrows the term crisis-proof from Husserl (cp. Eucken 1950/1965: 233).

${ }^{22}$ This disinterested and open-minded line of action recalls Husserl's epoché indicating an absolute impartiality and abstention, a desisting of rash conclusions and pre-assumptions, a bracketing of all our prior knowledge, and a behaving like a neutral and disinterested spectator. In combination with Husserl's transcendental-phenomenological and eidetic reduction it leads to a change of consciousness, to a pure and self-reflected consciousness, and to a scientific research of the essence and a priori cognition.

${ }^{23}$ Eucken aims at the exact recognition and the capture of the interdependencies of economic reality.

${ }^{24}$ For the importance of the morphological analysis of reality and the vision of everyday life as the starting point of Eucken's approach see Eucken 1938a and 2001: pp. 69.

${ }^{25}$ Cp. Foucault 2006: pp. 172

${ }^{26}$ The Eucken-term "invariant general form" is derived from Husserl's phenomenology; the same holds true for the expressions: "to the things", and "pointedly distinguishing abstraction".

${ }^{27} \mathrm{Cp}$. for further information about the eidetic order of freedom and the market: Kaufmann 1956, and for more information about the relationship of phenomenology and economics, and the phenomenological-based economists Gottl-Ottlilienfeld and Back: Goldschmidt 2002: pp. 71 and Rauchenschwandtner 2005; see also Miksch 1937/1947: p. 66 (i.e. 'phenomenology of competition').

${ }^{28} \mathrm{Cp}$. for indirect-implicit references to Husserl's concepts of epoché and transcendental-phenomenological reduction: Böhm, Eucken \& Großmann-Doerth 1936: 35, Eucken 1938a, 1940, 1952/2004: 1/370, 2001: pp. 71.

${ }^{29}$ In analogy to Kant we can say that theoretical scientific knowledge starts with experience and empiricism; it derives from simply looking at the facts of everyday life. In accordance with Kant Eucken claims that evident-objective knowledge and universal truths exist, however, they cannot rest upon experience alone. So Eucken has to untie his methodological approach from the empirical level, from the level of everyday economic life, and enter the theoretical and morphological level. After accomplishing this path of abstraction and ideal type he turns later on again towards the starting level - looking at it, however, from a different angle, from a different perspective and with a divergent insight. 
Although Eucken demands the absence of value judgments in a Weberian and Husserlian sense on the epistemological level, it is more than obvious that his socio-political and ethical theory is highly characterised by normative judgements - departing from Husserl's 'positivism' and marking the difference between phenomenology and Ordoliberalism.

${ }^{30}$ Cp. Hua III/1, Rudolf Eucken's Prolegomena to Studies on the Unity of Intellectual Life, and Eucken 1934: 20; it is remarkable that Walter Eucken does not distinguish between abstraction and reduction (cp. Goldschmidt 2002: pp. 54). That sets him apart from Husserl.

${ }^{31}$ In Vom Hauptproblem der Kapitaltheorie and Nationalökonomie wozu? Eucken mentions Thünen, a German economist, and his model of the isolated state (cp. Thünen 1850/1910). Thünen's method of isolating abstraction is quite similar to Eucken's own approach (not only in terminological aspects), and Eucken himself sings the praises of Thünen's methodology (he even called him "Master of Economics" (p. 39; cp. Eucken 1950/1965: 269). By referring to Thünen and others, Eucken confirms our supposition that the pointedly distinguishing or isolating abstraction technique not only has Husserlian roots - relativizing once again Husserl's influence and pointing at Eucken's eclecticism.

Moreover, the essay Vom Hauptproblem der Kapitaltheorie makes clear that the method established by the Historical School, namely the empirical-descriptive observation of reality and the collection of facts, alone is not sufficient. Thus, Eucken is indirectly criticizing the dominant paradigm in German economics (Eucken 1937: 544f.) and it seems at least doubtful whether Eucken is the climax of the Historical School as claimed by Schefold (2002: p. 7; 2003) and Broyer (2006).

${ }^{32}$ A term used by Rudolf Eucken (without publication date: 94) as well.

${ }^{33}$ Goldschmidt (2007: 12) refers to another similarity: Walter Eucken's distinction between actuality and truth equals Husserl's distinction between law and fact.

${ }^{34}$ Everyday economic life is Eucken's - and Weber's (cp. Eucken 1950/1965: 245) - methodological point of departure respectively his epistemological aim. However, he takes an indirect route or a circuit via his (rationalistic) method of abstraction and reduction, and by deducing ideal types, applying them to economic reality (and thus combining theoretical and historical, rationalistic and empiric elements). This - in short - is Eucken's solution to the economic Great Antinomy.

${ }^{35}$ The term realm of truth (as well as the process of reduction and the postulate of a perspective from within) is often used by Rudolf Eucken (cp. his Prolegomena), which is a further indication for the thesis that Walter Eucken favours an eclectic approach combining different elements from different scientists (cp. Eucken 1950/1965: 230-231).

${ }^{36}$ Eucken quotes Husserl's Philosophy as a Rigorous Science. This is one of the few occasions when Eucken literally borrows from other sources besides the LI. 
${ }^{37}$ The enhancement of particular aspects of the reality, and at the same time the neglecting of irrelevant aspects reminds on Weber's ideal-type-approach (cp. Weber 1968: 176/187/pp. 190, Goldschmidt 2002: pp. 43; 2007: 6, and Schäfer 1951).

${ }^{38}$ Cp. Eucken 1950/1992: 332: "In the abstraction of significant characteristics [...] the single aspects of any actual conditions are emphasized. In this way pure forms worked out [...]. "Generalising" abstraction, on the other hand, proceeds by surveying many facts and summarising the common characteristics of these facts in concepts.“

${ }^{39}$ Cp. Eucken 1950/1992: 228-229: "To apply the different ideal types of economic systems with their numerous variants it is necessary after defining and working out a morphology to return to the real economic world. But this time we approach it differently. Formerly we examined the individual phenomena [...], studied them from every standpoint, and in the course of our analysis extracted one by one the forms realised in each case [...]. Now we survey the whole economy $[\ldots]$. Previously we worked by abstracting the significant characteristics from the particular phenomenon, now by "generalising" abstraction."

${ }^{40}$ The same holds true for Philosophy as Rigorous Science published in 1911.

${ }^{41}$ One of the catchphrases of Husserl is: "Consciousness is always consciousness of something."

${ }^{42}$ The term life-world is a product of Rudolf Eucken('s book Mensch und Welt (1918b)): cp. Fellmann 2009: 37.

${ }^{43}$ Cp. Hua XXVII 20: "Renewal of humans, of the individual human as well as the communalized humanity, is the chief theme of all ethics“ (translated); see for an identical claim: Rudolf Eucken 1922: V ("necessity of an intellectual renewal“"(translated)), 58 and 82.

${ }^{44}$ One essential feature, and the quasi-basis of reforming the cultural and scientific system - and thus solving the current crisis -, is phenomenology as a scientific ethic, and the radical and ultimate foundation and justification of philosophy.

${ }^{45}$ Cp. Rudolf Eucken 1918a: pp. 122 and 1922; see Braun's introduction in: Rudolf Eucken 1918a: pp. 3; cp. Dathe 1996 and Fellmann 2009.

${ }^{46}$ Rudolf Eucken is highly critical of utilitarianism (cp. Rudolf Eucken 1950: p. 387) - a further parallel to Husserl (cp. Ms. B I 21 II, E III 2 and Hua XXVII: pp. 116, where Husserl condemns self-love, egoism, greed, striving for power, and (extensive) utilitarian thinking).

${ }^{47}$ Cp. Rudolf Eucken (without publication date): pp. 53 and pp. 87

${ }^{48}$ Cp. Rudolf Eucken 1922: pp. 70 and (without publication date): 59-60; see for more information about parallels of the noological and the phenomenological method: Goldschmidt 2002: pp. 83, Fellmann 1983 and 2009.

${ }^{49}$ Cp. Rudolf Eucken 1918a and (without publication date): pp. 66; see Fellmann 2009: pp. 32.

${ }^{50} \mathrm{Cp}$. Walter Eucken's letter dating from the $7^{\text {th }}$ of March 1936 
${ }^{51} \mathrm{Cp}$. letter from Walter Eucken to his mother dating from the $17^{\text {th }}$ of September 1936; see Walter Eucken's preface in Rudolf Eucken's book Die Lebensanschauungen der Großen Denker (1950: pp. V); noteworthy is the fact that Rudolf Eucken was also well educated in economic matters - especially in subjects related to Adam Smith, socialism, laissez faire, and the industrial revolution (i.e. social question and pauperism): cp. Rudolf Eucken 1950: 286/pp. 347 and 1920. All this might be a major contribution or might have had a major impact on Walter Eucken's own economic approach (cp. Eucken 1952/2004: 27).

${ }^{52}$ Walter Eucken (under the pseudonym Dr. Kurt Heinrich) as early as 1926 - i.e. before(!) personally knowing Husserl - talks of a necessary intellectual and cultural reformation. In this essay it becomes clear that Walter Eucken regards himself as a disciple of his father.

53 Cp. Goldschmidt 2002: 85 and Goldschmidt \& Rauchenschwandtner 2007: 21; Rudolf Eucken's Geisteslebensphilosophie is in some respect even the forerunner and predecessor of Husserl's phenomenology.

${ }^{54}$ Yet, several scattered anecdotes and comments on politics relating subjects can be found in the oeuvre of Husserl. Interestingly many of Husserl's disciples were applying phenomenology to sociology, jurisprudence, and economics: e.g. Kaufmann (1956; cp. Husserl 1994a: 181), Reinach, and Schütz (cp. Madison 1997 and Prendergast 1986 for information about Schütz' affiliation with the Austrian School of Economics); see for a brief overview of Husserl's followers and members of the phenomenological movement: Gerlach \& Sepp 1994: pp. 423. Some of Husserl's disciples were later on political activists or politicians themselves: e.g. Anders, one of the initiators of the anti-atommovement, or Patočka, one of the authors of the Charta 77).

${ }^{55}$ Cp. Gerhart Husserl 1940 and 1969.

${ }^{56}$ Cp. Husserl 1994a: 197-198 /220/236 and Fink \& Patočka 1999: 44-45

${ }^{57}$ Cp. Schuhmann 1988

${ }^{58}$ Breda (1973) sees radical (inalienable) freedom and autonomy of man as the fundamental hypothesis of Husserl (cp. Husserl's signing of Romain Rolland's and the League for the Promotion of Humanity's appeal for independency and autonomy, reprinted in: Sepp 1988: 308-309); according to Husserl the potential (socio-political) menace to freedom can be overcome via transcendental-phenomenological reduction.

${ }^{59}$ Another categorical imperative of Brentano as well as Husserl is: "Do what is best, and do it with rational evidence“ (translated); Hua XXVIII 142).

${ }^{60}$ Walter Eucken regards individual freedom as the central precondition for social security and justice; therefore, freedom (in addition with an adequate ordering) is a part of solving the social question; (Kantian) freedom and autonomy are for both Husserl and Eucken right at the heart of their theories. Cp. for parallels between Walter Eucken and Kant: Klump \& Wörsdörfer 2010 and Wörsdörfer 2010. 
${ }^{61}$ As cited in the English edition of the Crisis-work: Husserl,E. (1970): "The Crisis of European Sciences and Transcendental Phenomenology"; Evanston, Northwestern UP; pp. 338.

${ }^{62}$ Husserl's preference for an (ordoliberal), constitutional state (which is primarily oriented by the ideal of reasonableness and rationality) is a further parallel to Eucken.

${ }^{63}$ Eucken is constantly referring to a functioning and humane ordering; cp. for detailed information about phenomenology and ordering: Wetz 1995: pp. 110.

${ }^{64}$ See for more information about the phenomenon law and the role of sanctions: Hua XIII pp. 105 and XV pp. 421 and 510 (the latter passage is in our context remarkable because Husserl is discussing the phenomenon of power and authority (s. also XIV 215).

${ }^{65}$ Phenomenology is mainly responsible for overcoming mental immaturity, and reaching autonomy and selfconfidence. Transcendental philosophy incorporates a claim to phenomenological leadership similar to that of Platonism (i.e. philosopher kings). Phenomenologically trained persons are the teachers of the people, they are the bearers of rationality, and they teach and educate their milieu until a phenomenological movement and finally an overall phenomenological society has been established (Ms. K III 9/64a and K VI 334); cp. for a similar elitist understanding of science Eucken 1952/2004: pp. 338.

${ }^{66} \mathrm{Cp}$. for Husserl's support for democracy: Trincia 2007: 185.

${ }^{67}$ Cp. Husserl 1994a: 224

${ }^{68}$ The relationship between self-interest and public welfare is a topic discussed intensely by Walter Eucken (cp. e.g. Eucken: 1952/2004: pp. 355).

${ }^{69}$ See for a similar judgement on power by Husserl: Ms. A V 5 and B I 21 II.

${ }^{70}$ The English translations of Eucken's key terms are taken from Vanberg 2004; further keywords of Eucken in this context are: thinking in orders and the interdependency of orders.

${ }^{71}$ Cp. for the Neokantian and Neoidealistic influence on Eucken: Nawroth 1961/1962.

${ }^{72}$ Eucken belonged to the core group of the Freiburg Circles, a resistance movement opposing National Socialism. He was one of the university-intern opponents to Heidegger's attempt to establish the Führerprinzip and the Gleichschaltung at the university, and he risked his life in fighting Nazi ideology, propagating ordoliberal ideals for a new socio-political and economic ordering for the post-war-period (cp. Dietze, Eucken \& Lampe 1941/1942), and of course due to his remaining contact with persons who fell in disgrace under the Third Reich dictatorship. Walter Eucken received death threats after his lectures Kampf der Wissenschaft, the second edition of his book Nationalökonomie $w o z u$ ? was prohibited, and he was arrested and interrogated after the failed July 20 plot. This is all the more astonishing reminding the fact that Eucken's mother in law was due to the NS-racial laws a Jew, his wife Edith was a half-Jew, and Walter Eucken himself was classified as non-Arian (interrelated) (cp. Oswalt 2005, Goldschmidt 1997, and 2005). 
${ }^{73}$ As cited in: Lenel,H.O. 1991: Walter Euckens Briefe an Alexander Rüstow; Ordo 42, 11-14 (here p. 12).

${ }^{74}$ For more information on the meta-economical Vermassungs- (i.e. massification and stereotyping process), Gesellschaftskrisis- and Kulturkritik-topic cp. Heinrich 1926; Eucken 1932b; see also Renker 2009.

${ }^{75}$ Cp. Dathe \& Goldschmidt 2003

${ }^{76}$ Malvine Husserl: Skizze eines Lebensbildes von E. Husserl; as cited in Gerlach \& Sepp 1994: 30; see Ms. A V $21 / 15 b / 20 a / 24 b / 25 a$

${ }^{77}$ Cairns 1976: 52

${ }^{78}$ In his essay Die Überwindung des Historismus Eucken refers explicitly to Husserl's Logical Investigations and his Crisis-work claiming that Husserl as well as Rudolf Eucken are among the few contemporary philosophers criticizing historism for its alleged relativism, fatalism, determinism and irrationalism (i.e. seventh explicit quote).

${ }^{79}$ Cp. Eucken 1952/2004: 340, Husserl's concept of epoché and Rudolf Eucken (without publication date): 86.

${ }^{80} \mathrm{Cp}$. Grossekettler 2003: 31 and Goldschmidt 2007: 14: “... the fact that Eucken uses abstraction does not make him a phenomenologist. [...] It would thus be fairer to argue that Eucken's method of abstraction links him to Husserl only on the basis of its intention, i.e. the search for truth - while the method itself was developed through the analysis of the ideal type discussion relating to Weber and reverting to Thünen." This statement holds true not only on the epistemological level.

${ }^{81}$ Of course the epistemologist Eucken runs to a certain degree a phenomenology of the economic life world, but the slogan touches on the crucial point: he combines (among others) Husserl's phenomenology with Rudolf Eucken's concept of the life world.

\section{References}

BÖHM,F., EUCKEN,W. \& GROSSMANN-DOERTH,H. (1936): Unsere Aufgabe in: Goldschmidt \& Wohlgemuth (eds.) (2008): Grundtexte zur Freiburger Tradition der Ordnungsökonomik; Tübingen, Mohr Siebeck

BRAUN,O. (1918): Rudolf Eucken und sein Werk in: Geistesprobleme und Lebensfragen; Leipzig, Reclam

BRECHT,F.J. (1957): Edmund Husserl in: Heimpel, Heuss \& Reifenberg (eds.): Die Großen Deutschen. Deutsche Biographie; Berlin, Propyläen

BREDA,H.L.v. (1973): Husserl und das Problem der Freiheit in: Noack (ed.): Husserl; Darmstadt, Wissenschaftliche Buchgesellschaft

BROYER,S. (2006): Die Hinterlassenschaft der historischen Schule in Walter Euckens Ordnungstheorie und dem deutschen Ordoliberalismus “; Frankfurt am Main, unpublished doctoral dissertation (University of Frankfurt).

DATHE,U. (1993): Eine Ergänzung zur Biographie Edmund Husserls in: Stelzner (ed.): Philosophie und Logik - Frege Kolloquien Jena 1989/1991; Berlin, de Gruyter 
- (1996): Begriffsgeschichte und Philosophie. Zur Philosophie Rudolf Euckens in: Caysa \& Eichler (eds.): Philosophiegeschichte und Hermeneutik; Leipzig, Leipziger Universitätsverlag

- (2009): "Zu sehr hatte ich mich auf die Begegnung mit dem großen Denker gefreut«Walter Euckens Weg zu Edmund Husserl; in: Gander, Goldschmidt \& Dathe (eds.): Phänomenologie und die Ordnung der Wirtschaft; Würzburg, Ergon DATHE,U. \& GOLDSCHMIDT,N. (2003): Wie der Vater so der Sohn? Neuere Erkenntnisse zu Walter Euckens Leben und Werk anhand des Nachlasses von Rudolf Eucken in Jena; ORDO 54, 49-74

DIETZE,C.v., EUCKEN,W. \& LAMPE,A. (1941/1942): Volkswirtschaftsfibel; Nachlass Popitz, Bundesarchiv Koblenz EUCKEN,R. (1885): Prolegomena zu Forschungen über die Einheit des Geisteslebens in Bewußtsein und That der Menschheit; Leipzig, Veit

- (1918a): Geistesprobleme und Lebensfragen - Ausgewählte Abschnitte aus den Werken Rudolf Euckens; Leipzig, Reclam

- (1918b): Mensch und Welt; Leipzig, Quelle \& Meyer

- (1920): Der Sozialismus und seine Lebensgestaltung; Leipzig, Reclam

- (1922): Lebenserinnerungen - Ein Stück deutschen Lebens; Leipzig, Koehler

- (1924): Die Bedeutung des wissenschaftlichen Zusammenstrebens der Völker; Japanisch-Deutsche Zeitschrift für Wissenschaft und Technik 2, 4-7

- (1950): Die Lebensanschauungen der Großen Denker; Berlin, de Gruyter

- (?): Philosophische Schriften; Zürich, Coron

EUCKEN,W. (1908-1926/1935-1937): Briefe von Walter Eucken; Jena, Thüringer Universitäts- und Landesbibliothek: Nachlass Irene und Rudolf Eucken

- (1927): Vom Radikalismus sozialistischer und Euckenscher Prägung; Die Tatwelt, JG III, Heft 1/3, 44-48

- (1930): Wirtschaftsentwicklung contra Kulturentwicklung; Die Tatwelt, JG VI, Heft 1, 33-37

- (1932a): Religion - Wirtschaft - Staat; Die Tatwelt, JG VIII, Heft 2, 82-89

- (1932b):,,Staatliche Strukturwandlungen und die Krisis des Kapitalismus; WWA, Bd. 36, 297-321

- (1933): Denken - Warum?; Die Tatwelt, JG IX, Heft 3, 148-152

- (1934): Kapitaltheoretische Untersuchungen. Mit einer Einleitung in die Sammlung: Was leistet die nationalökonomische Theorie?; Jena, Fischer

- (1935): Wiedersehen mit den Bildern von August Macke; Frankfurter Zeitung (23.10.1935)

- (1937): Vom Hauptproblem der Kapitaltheorie; Jahrbücher für Nationalökonomie und Statistik 145, 533-564

- (1938a): Nationalökonomie wozu?; Leipzig, Meiner

- (1938b): Die Überwindung des Historismus; Schmollers Jahrbuch 62, 191-214

- (1940): Wissenschaft im Stile Schmollers; WWA, Bd. 52, 468-506 
- (1950): Vorwort in: Eucken, Rudolf: Die Lebensanschauungen der Großen Denker; Berlin, de Gruyter

- (1950/1965): Die Grundlagen der Nationalökonomie; Berlin, Springer

- (1950/1992): The Foundations of Economics. History and Theory in the Analysis of Economic Reality; Berlin, Springer

- (1952/2004): Grundsätze der Wirtschaftspolitik; Tübingen, Mohr Siebeck

- (2001): Wirtschaftsmacht und Wirtschaftsordnung; Münster, LIT

EUCKEN-ERDSIEK,E. (1981): Magie der Extreme; Freiburg, Herderbücherei

FELlMANN,F. (1983): Gelebte Philosophie in Deutschland. Denkformen der Lebensweltphänomenologie und der kritischen Theorie; Freiburg, Alber

- (2009): Das Werk Rudolf Euckens als weltanschaulicher Rahmen für die Freiburger Phänomenologie Husserls; in:

Gander, Goldschmidt \& Dathe (eds.): Phänomenologie und die Ordnung der Wirtschaft; Würzburg, Ergon

FINK,E. \& PATOČKA,J. (1999): Briefe und Dokumente, 1933-1977; Freiburg, Alber

FOUCAULT,M. (2006): Die Geburt der Biopolitik. Geschichte der Gouvernementalität II; Frankfurt, Suhrkamp

GERLACH,H.M. \& SEPP,H.R. (eds.) (1994): Husserl in Halle. Spurensuche im Anfang der Phänomenologie; Frankfurt, Lang

GOLDSCHMIDT,N. (1997): Die Entstehung der Freiburger Kreise in: Konrad Adenauer Stiftung (ed.): HistorischPolitische Mitteilungen; Köln, Böhlau

- (2002): Entstehung und Vermächtnis ordoliberalen Denkens - Walter Eucken und die Notwendigkeit einer kulturellen Ökonomik; Münster, LIT

- (2003): Theorie auf normativer Basis: Anmerkungen zum ordoliberalen Konzept von Walter Eucken in: Commun, P. (ed.): L'ordolibéralisme allemande - Aux sources de l'Economie sociale de marché; Cergy-Pontoise, CIRAC/CICC

- (2005): Die Rolle Walter Euckens im Widerstand: Freiheit, Ordnung und Wahrhaftigkeit als Handlungsmaximen; in Goldschmidt (ed.): Wirtschaft, Politik und Freiheit - Freiburger Wirtschaftswissenschaftler und der Widerstand; Tübingen, Mohr Siebeck

- (2007): Walter Eucken's Place in the History of Ideas; retrieved March 25, 2009 from:

www.gmu.edu/centers/publicchoice/HES\%202007/papers/6d\%20goldschmidt.pdf

- (2009): Das Reich der Wahrheit und die Lebensordnung. Welche Spuren haben Rudolf Eucken und Edmund Husserl in den Arbeiten von Walter Eucken hinterlassen?; in: Gander, Goldschmidt \& Dathe (ed.): Phänomenologie und die Ordnung der Wirtschaft; Würzburg, Ergon

GOLDSCHMIDT,N. \& RAUCHENSCHWANDTNER,H.: (2007): The Philosophy of Social Market Economy: Michel Foucault's Analysis of Ordoliberalism; retrieved March 25, 2009 from:

http://opus.zbw-kiel.de/volltexte/2007/6684/pdf/07_4bw.pdf 
GRAF,F.W. (1996): Die gescheiterte Berufung Husserls nach Jena - Drei unbekannte Briefe; Dilthey-Jahrbuch 10, 135-142

GROSSEKETTLER,H.: (2003): Walter Eucken; Münster, Volkswirtschaftliche Diskussionsbeiträge

HEINRICH, Dr. Kurt (alias Walter Eucken) (1926): Die geistige Krise und der Kapitalismus; Die Tatwelt JG II, Heft $1 / 3,13-16$

HERRMANN-PILLATH,C. (1991): Der Vergleich von Wirtschafts- und Gesellschaftssystemen: Wissenschaftsphilosophische und methodologische Betrachtungen zur Zukunft eines ordnungstheoretischen Forschungsprogramms; ORDO 42, 1991, 15-68

HUSSERL,E. (1927): Die Phaenomenologie und Rudolf Eucken; Die Tatwelt, JG III, Heft 1/3, 10-11

- (1956): Persönliche Aufzeichnungen; Philosophy and Phenomenological Research, Vol. 16, No. 3, 293-302

- (1973a-c): Zur Phänomenologie der Intersubjektivität; Den Haag, Nijhoff (Hua XIII-XV)

- (1975): Logische Untersuchungen: Bd.1: Prolegomena zur reinen Logik; Den Haag, Nijhoff (Hua XVIII) (in English: Logical Investigations Vol.1)

- (1976): Die Krisis der Europäischen Wissenschaften und die Transzendentale Phänomenologie; Den Haag, Nijhoff

(Hua VI) (in English: The Crisis of European Sciences and Transcendental Phenomenology)

- (1988): Vorlesungen über Ethik und Wertlehre 1908-1914; Dordrecht, Kluwer (Hua XXVIII)

- (1989): Aufsätze und Vorträge (1922-1937); Dordrecht, Kluwer (Hua XXVII)

- (1992a): Idee zu einer reinen Phänomenologie und phänomenologischen Philosophie; Hamburg, Meiner (Hua III + V) (in English: Ideas: General Introduction to Pure Phenomenology)

- (1992b): Erste Philosophie (1923/4); Hamburg, Meiner (Hua VII + VIII) (in English: First Philosophy)

- (1992c): Logische Untersuchungen. Untersuchungen zur Phänomenologie und Theorie der Erkenntnis; Hamburg, Meiner (Huа XIX)

- (1993): Die Krisis der Europäischen Wissenschaften und die Transzendentale Phänomenologie. Ergänzungsband; Dordrecht, Kluwer (Hua XXIX)

- (1994a): Briefwechsel - Band IV: Die Freiburger Schüler; Dordrecht, Kluwer

- (1994b): Briefwechsel - Band VI: Philosophenbriefe; Dordrecht, Kluwer

- (1994c): Briefwechsel - Band IX: Familienbriefe; Dordrecht, Kluwer

HUSSERL,G. (1940): Men and the Law“ in: Farber (ed.): „Philosophical Essays in Memory of Edmund Husserl; Cambridge, HUP

- (1969): Person, Sache, Verhalten. Zwei phänomenologische Studien; Frankfurt, Klostermann

KAUFMANN,F. (1956): Die ökonomischen Grundbegriffe - Eine Studie über die Theorie der Wirtschaftswissenschaft; Journal of Economics, Vol. 15, No.3, 304-316 
KLINCKOWSTROEM,W. (2000): Walter Eucken: Eine biographische Skizze in: Gerken (ed.): Walter Eucken und sein Werk; Tübingen, Mohr Siebeck

- (2005): Zum 20. Todestag: Der Lebensweg von Edith Eucken-Erdsiek (1896-1985); retrieved March 25, 2009 from http://walter-eucken-institut.de/publikationen/ jahresbericht2005.PDF

KLUMP,R. (2003): On the phenomenological roots of German Ordnungstheorie: what Walter Eucken ows to Edmund Husserl; in: Commun (ed.): L'ordolibéralisme allemande - Aux sources de l'Economie sociale de marché; CergyPontoise, CIRAC/CICC

KLUMP,R. \& WÖRSDÖRFER,M. (2010): An Ordoliberal Interpretation of Adam Smith; in: The Ordo Yearbook of Economic and Social Order

MADISON,G.B. (1997): Economics; Encyclopedia of Phenomenology; Dordrecht, Kluwer

MEIJER,G. (2007): Value and Exchange in Economic Theorizing: The Contribution of the Freiburg School in: The Review of Austrian Economics 20; pp. 171-185.

MIKSCH,L. (1937/1947): Wettbewerb als Aufgabe; Godesberg, Küpper

MOHANTY,J.N. (1995): The Development of Husserl's Thought in: Smith,B. \& Smith,D.W. (ed.): The Cambridge Companion to Husserl; Cambridge, CUP

NAWROTH,E.E. (1961/1962): Die Sozial- und Wirtschaftsphilosophie des Neoliberalismus; Heidelberg, Kerle

OSWALT,W. (2005): Liberale Opposition gegen den NS-Staat - Zur Entwicklung von Walter Euckens Sozialtheorie; in Goldschmidt (ed..): Wirtschaft, Politik und Freiheit - Freiburger Wirtschaftswissenschaftler und der Widerstand; Tübingen, Mohr Siebeck

PRENDERGAST,C. (1986): Alfred Schutz and the Austrian School of Economics; The American Journal of Sociology, Vol. 92, No.1, 1-26

RAUCHENSCHWANDTNER,H. (2005): Soziale Erkenntniskritik, Wesenswirtschaft und national-sozialistische Weltanschauung mit besonderer Berücksichtigung von Josef Back in: Goldschmidt (ed.): Wirtschaft, Politik und Freiheit; Tübingen, Mohr Siebeck

RENKER, Jan (2009): Die Krisis der Moderne bei Rudolf Eucken, Edmund Husserl und Walter Eucken; in: Gander, Goldschmidt \& Dathe (eds.): Phänomenologie und die Ordnung der Wirtschaft; Würzburg, Ergon

SCHÄFER,M. (1951): Die logische Struktur des Idealtypus bei Max Weber, Walter Eucken und Wilhelm Vershofen; unpublished doctoral dissertation, University of Nuremberg

SCHEFOLD,B. (2002): Markt, Politik und Gesellschaft bei Wilhelm Röpke in: Blankart,F.A./Peukert, H./ Schefold,B./Starbatty,J. (eds.): Wilhelm Röpkes »Die Gesellschaftskrisis der Gegenwart« Vademecum zu einem Klassiker der Ordnungstheorie; Düsseldorf, Verlag Wirtschaft und Finanzen 
- (2003): Die deutsche Historische Schule als Quelle des Ordoliberalismus; in: Commun,P. (ed.): L'ordolibéralisme allemande - Aux sources de l'Economie sociale de marché; Cergy-Pontoise, CIRAC/CICC

SCHUHMANN,K. (1988): Husserls Staatsphilosophie; Freiburg, Alber

SEPP,H.R. (ed.) (1988): Edmund Husserl und die Phänomenologische Bewegung; Freiburg, Alber

THÜNEN,J.H.v. (1850/1910): Der isolierte Staat in Beziehung auf Landwirtschaft und Nationalökonomie. Zweiter Teil; Jena, Fischer

TRINCIA,F.S. (2007): The ethical imperative in Edmund Husserl; Husserl Studies, Vol. 23, No. 3, 169-186

VANBERG,V.J. (2004): The Freiburg School: Walter Eucken and Ordoliberalism; retrieved March 25, 2009 from: www.eucken.de/publikationen/04_11bw.pdf

VONGEHR,T. (2009): „Euckens sind wieder da, verstehende und so wertvolle Freunde“ - Die Freundschaft der Husserls zu Walter und Edith Eucken in den letzten Freiburger Jahren; in: Gander, Goldschmidt \& Dathe (eds.): Phänomenologie und die Ordnung der Wirtschaft; Würzburg, Ergon

WEBER,M. (1968): Gesammelte Aufsätze zur Wissenschaftslehre; Tübingen, Mohr Siebeck

WEISZ, J.D. (2001): A Systematic Perception of Eucken's Foundations of Economics in: Labrousse/Weisz (eds.): Institutional Economics in France and Germany. German Ordoliberalism versus the French Regulation School; Berlin, Springer

WETZ,F.J. (1995): Edmund Husserl; Frankfurt, Campus

WÖRSDÖRFER,M. (2010): Über die Wirtschaftsethik Walter Euckens; in: Konrad Adenauer Stiftung (ed.): 60 Years of Social Market Economy. Formation, Development and Perspectives of a Peacemaking Formula; Konrad Adenauer Stiftung, Sankt Augustin/Bonn, pp. 20-41 